\title{
THE IMPACT OF CAREER OPPORTUNITIES ON EMPLOYEE RETENTION IN HOSPITALITY INDUSTRY: A COMPARATIVE STUDY OF GARHWAL AND KUMAUN REGION OF UTTARAKHAND
}

\author{
Kumar Satyam \\ Research Scholar, Uttarakhand Technical University, Dehradun, Uttarakhand, India \\ Dr. Neeraj Aggarwal \\ Panjab University, Chandigarh, India \\ Dr. Yashpal Negi \\ State IHM, New Tehri, Uttarakhand, India
}

\begin{abstract}
Hospitality industry is one of the most dynamic industry. Guests enjoy their stay in hotels just because of high level of energy among its employee. This industry personnel are also known as most disciplined ones with reference to other sectors. The employee in hotels and other accommodation sectors are working in a set hierarchial structure of the organization. In every department, the career opportunity for working employees is their desired goal. They want to see working themselves on higher level on their every present situation. Apart from this, employees keep themselves motivated from other multiple reasons. If they don't find in the state of lacking in terms of motivation and career opportunity in their job, they start thinking to shift from one job to another. The hospitality industry in Uttarakhand is also facing challenges regarding employee retention. Retaining the competent employee in organization is considered as a significant task for the managers. Employees leave their organization due to multiple reasons, which they generally don't want to discuss with their managers. Sometime, even they don't know why they intend to change their organization. Frequency of changing the job and shifting from one organization to other is a known tendency among young employee.

In this research paper, the emphasis has been done on the various factors associated with employees' attrition related to motivation and career opportunities in hospitality industry of Uttarakhand. A comparative study has been done in Garhwal and Kumaon region of the state to know about the HR strategies adopted by hospitality industry in Uttarakhand regarding factors related to motivation and career
\end{abstract}


The Impact of Career Opportunities on Employee Retention in Hospitality Industry: A Comparative Study of Garhwal and Kumaun Region of Uttarakhand

opportunities. For this study, the hotels in both of regions have been identified for primary data collection and these hotels are ranging from three-star category and above. A set pattern of questionnaire as a research tool has been developed to assemble the data. Then the data-analysis has been done to find the conclusion that how motivation and career opportunities in hospitality industry is playing the significant role.

Key words: Motivation, Career opportunities, HR Strategies, Hospitality Industry, Employee- Retention, Garhwal and Kumaun Region, Uttarakhand

Cite this Article: Kumar Satyam, Dr. Neeraj Aggarwal and Dr. Yashpal Negi, The Impact of Career Opportunities on Employee Retention in Hospitality Industry: A Comparative Study of Garhwal and Kumaun Region of Uttarakhand, International Journal of Management, 11(12), 2020, pp 1065-1074.

http://iaeme.com/Home/issue/IJM?Volume=11\&Issue=12

\section{INTRODUCTION}

It is said the Uttarakhand is like a heaven on earth. The state has many popular tourist destinations since a very long time. people used to visit this state very often for many reasons. They come here year as pilgrims, as nature lover, as excursionist and as tourist. The advantage of Uttarakhand is its diversity. There are hills, fountains, lakes, wildlife, and many more reason to visit Uttarakhand. Garhwal and Kumaon region are two geographical regions of Uttarakhand respectively West and East part of the state.

Since Uttarakhand has come into existence, it is known as state whose economy can be flourished with tourism industry. Seeing the diverse opportunities in tourism industry, the state government has provided many supports to develop the hospitality industry. Badrinath and Kedarnath are two major pilgrim stations for the Hindus devotees, on the other side Gangotri and Yamunotri are playing their role as satisfying the extra need of tourism. Combinedly; they are known as Char Dham in Uttarakhand. Apart from these places there are many other pilgrim sites across the state. Sikhs use to visit Dehradun and Hemkunt Sahib every year. The tourism in the state is overloaded in the seasons; but during off-season it comes into a lean period. Generally, it is said that from May to October, tourists visit this place in huge numbers. The Chardham-Yatra provides the livelihood to the natives of entire state. All the sectors of tourism; ranging from transportation, hospitality, hotels and catering are completely occupied to serve the tourists. During the season, the devotees also visit many other places like Devprayag, Karnprayag, Nandprayag, Vishnuprayag, Gopeshwar, Rishikesh, Neelkanth Mahadev, Gaurikund, Tungnath, Har ki Pauri. While talking about the rejuvenation and excursion, there are many places like Ranikhet, Nainital, Ramnagar, Jim Corbett National Park, Rajaji National Park in the state. Kausani, Binsar, Baijnath, Almora and Haldwani are naturally beautiful places where tourist footfall is very large in number throughout the year. In the summers; people use to visit Mussoorie and Nainital, which are having very close proximity from New Delhi. But the tourism is adversely affected the rainy season and winters. Along with tourism; the industrial zones are also developing in the state, which attracts the industrialist to invest their money. Rudrapur, Kathgodam, Roorkee, Kotdwar, Haridwar, Dehradun are emerging places for industries.

\section{UTTARAKHAND: HOSPITALITY INDUSTRY}

To support the tourism industry, there are many entrepreneurs, who have established their property as hotels, resorts, spa-destinations, tents around the river banks etc. The hospitality arrangements in Uttarakhand is not in modern shape, but it is emerging and budding to get a benchmark. Garhwal and Kumaon regions of Uttarakhand are blessed with almost equal 
natural resources to flourish tourism industry. But it can't survive without the support of hospitality industry. The versatile landscapes, support system for electricity supply, water supply and transportation are equally distributed in both of the regions. Nature has also given equal opportunity to Garhwal and Kumaon in terms of tourism destinations. People visit these places with interest and they enjoy their stay during the vacations. Many of the hotels exist in these destinations since a long time in the form of Bungalow, Kothi, Rest-house, Guesthouse and resorts. Most of them were operated by government agencies with very minimum and basic facilities. Few of other accommodation facilities were run by tourist department of the state; GMVN and KMVN. But as the private properties and firms have seen the opportunities and the came to develop the hotels and similar setups.

The natives of Uttarakhand are known for their hospitality services throughout the world. Reaping the opportunity, the entrepreneurs in hospitality industry have taken it as advantage. The people of Uttarakhand have also got employment to earn money for their livelihood along with the emerging and growing prospects of Tourism and Hospitality. Side by side, it has been observed that, the migration from Uttarakhand have ceased in a fraction, but it is not satisfactory and can't be counted in record. The level of education is not equally similar throughout in state. Less educated people but skilled in hospitality services are moving up from villages to town. Relevant skilled people are employed in the hotels of Uttarakhand, but the hospitality industry is not able to attract people from outside. There are be many reasons behind it. Many-times it has been seen that after a few periods of time these local people also move out from the state to earn money. Somewhere they find the lack of motivation and career opportunity to retain themselves in the similar hotel property for a longer period of time.

\section{EMPLOYEE RETENTION VS. EMPLOYEE TURNOVER}

Staff turnover is usually defined as number of employees leaving the organisation within a given time period (Taylor 2008). Employees leave their organisation because of lack of supervisor's support, inadequate wages and salary, low opportunity of training and development and job dissatisfaction (Kemelgor and Meek 2008). In Casino, if employee attrition rate is high, it has a direct effect on the business, customers loyalilty is lost for the firm and ultimately business is hampered (Agrusa and Lema, 2007). It is very difficult to retain the value of employees in an organisation and equally it is a challenge for the HR managers the crew recruit the good employees (Panoch, 2001). The talented employees are playing versatile role in organisation and they are the backbone of future planning (Martin 2010). Recruitment of employee involves a lot of cost, it covers the cost in training and development also; therefore, it is important that qualified employees should be retained in the organisation (Padron, 2004). Taylor (2008) argues that hotels and restaurants have highest attrition rate compared to any other industry.

Attrition of employees is always challenging for every organisation throughout the world (Sinha and Sinha, 2012). No matter, whether the organisation the is big or small, it suffers with bad consequences because of Employee turnover in a larger ratio (Haung et al, 2016). Iqbal (2017) says that It is proportionate to the employee retention with their job satisfaction. Employee turnover is a threat for or operational activities and it affects the productivity and efficiency (Deery \& Shaw, 1997; Lashley \& Chaplain, 1999). The hotel industry is having highest level of employee turnover and in USA about 50\% management employees leave their jobs every year (Anthony \& Irene, 2014). 


\section{HR STRATEGIES FOR CAREER OPPORTUNITY}

Employees are motivated when they find satisfied in their job. Job satisfaction is the stage, where an employee is having a feel of Pride for his job and when someone praises the values for job (Kara, et al., 2012). When the employee feels dissatisfaction in his stagnant job, it leads to thought for leaving the organisation and hence attrition causes (Robinson \& Beesley, 2010). There are many factors to keep employee motivated in his job, it includes healthy environment, good remuneration, appreciation at workplace, employee friendly working conditions, career growth and promotions in the organisation (Honore, 2009). Once the organisation recognize that what are the crucial factors to keep employee motivated, it is able to retain them for a longer time (Chikwe, 2009).

Among the other factors of motivation "reward" is having an important role in motivation. Organisations use to keep employees motivated by various reward systems. Sometimes incentives, gifts, bonus are being offered by the management to keep the employee happy. few of the organisation have different practices to keep the employees "highlighted" as "Start of the Month" along with their performance in organisation. These kinds of recognition are generally announced monthly, quarterly, biannually or annually in the hotels. These rewards are playing crucial role in career development (Salie \& Schlechter, 2012). For this, the organisations are adopting various reward strategies so that the employee must enjoy your job. In the service industry, it is very important to keep their employees motivated (Bursch, 1999). In the hospitality industry, appreciation in various forms give positive impacts among the employees and keep the work environment lively; which leads to employee retention (Levine, 2005). It has been observed that male employees are more satisfied rather than females in their job. It is also affected by age, gender and span of services in an employment (Kara, et al., 2012).

Career growth is very important for everyone. All the employees in the organization are expecting a well-planned career opportunity for their development. It has been found in studies that female employees are expecting generally flexible timing in job and child-care facilities in the organisation so that they can work freely (Panoch, 2001). Improper balance between work and remuneration is the major problem in hospitality industry and it leads to the dissatisfaction in career growth in terms of promotion and increment in salary (Bharwani $\&$ Butt, 2012). It is a human tendency that it cannot work for a longer in a similar position until skill and educated. Promotion ion job is always expected, in the terms of enhancement in salary, power, authority and ultimately the recognitions in the organisation. While finding these by the employees, it affects the employee-retention in the organisation (Moncarz, 2008).

Hospitality industry is taken as second choice by many people because of its less as well as undefined career growth and structure (Richardson, 2008). In the early phase of employment, hospitality personnel enjoy their job in hotel industry as it seems like lucrative. But along with the time lap, a feeling of unpleasant and disrespect in the job are felt by them. They find no social status of hospitality personnel. It drives to lack of motivation as the salary and other components are not comparative good rather than other industries (Davidson, et al., 2011).

Syahreza et al. (2017) says that the employees are motivated with financial gains. The satisfaction in job leads to motivation and power on it is the positive impact in retaining the employees (Iqbal et al., 2017). Employees turnover is not only caused by lack of motivation, there are other factors also (Bettye, L., 2018). The organisation should consider about professional development, career path, promotion and growth in remuneration for the employees (Folakemi et al, 2018). Employees falling in different age group and level of education have their different intention for change of employment (Vetráková,et al, 2019). Employee retention strategies plays the significant role in their behavioural outcomes. The 
management should continuously work for employees' career-development and their financial stability. Positive workplace behaviour develops the employers' branding (Folakemi, et al., 2020). Career growth is the symbol of career commitment and organisational identification. The employee turnover intention is negatively related to career commitment (Yifei, L., 2018). Career adaptability is negatively related to employee turnover intention. While illustrating Career Construction Theory (CCT); it is important to consider about employee's turnover intention with the reference to career growth and opportunity (Rasheeda et al 2020).

\section{OBJECTIVES OF THE STUDY}

- To evaluate the effectiveness of career opportunities in the retention of employees.

- To study the relationship between HR strategies career opportunity and employee retention.

\section{Hypothesis}

$\mathrm{H}_{0}$ : There is a significant influence of career opportunities on HR strategies of employee retention.

$\mathrm{H}_{1}$ : There is no significant influence of career opportunities on HR strategies of employee retention

\section{RESEARCH METHODOLOGY}

The objective of this research study is to investigate about HR strategies for career opportunities of employees in hotels of Uttarakhand. Both in Garhwal and Kumaon regions, there may be different factors related to career-growth and opportunities for employees. In this research study, a cross examination of factors related to career development has been examined in both of the region. There may be multiple reasons to move from the working organisation for its employees. This study will help in identifying the possible reasons behind it to minimise the employees-turnover and associated cost in their recruitment, training and development.

The three star and above category hotels in both of the regions of Uttarakhand have been taken to conduct the study. The working employees in hotels, have been used as sample for this research study. The respondents have been segregated as per "random sampling method". A well-structured questionnaire have been developed to collect the primary data in personal observation of the researcher. Total 350 employees from various hotels of Uttarakhand have been selected for data collection; 175 employees from the hotels of Garhwal and similar number of employees have been taken from hotels of Kumaon region. To collect the secondary data, the research papers, journals, various publications by government agencies, books had been used.

\subsection{Analysis}

The primary data collected for employees of hospitality industry from Garhwal and Kumaon regions having taken as reliable sample after a reliability test. A total of 350 samples have been taken from entire state, as mentioned earlier 175 samples from each region i.e. Garhwal and Kumaon. The initial part of analysis is showing the reliability and validity of issues; and other part of result is showing about various identified factors with employee retention in terms of career opportunity. 


\subsection{Validity and reliability of Issues Identified}

For measuring the rationality of identified issues; the Principal Component-Analysis with exploratory factor analysis has been done with VARIMAX rotation. Cronbach's Alpha has been used to check the Reliability of data.

Table 1 Gender distribution of the respondents

\begin{tabular}{|c|l|c|c|c|c|}
\hline \multicolumn{6}{|c|}{ Gender } \\
\hline \multirow{2}{*}{} & Frequency & Percent & Valid Percent & $\begin{array}{c}\text { Cumulative } \\
\text { Percent }\end{array}$ \\
\hline \multirow{3}{*}{ Valid } & Female & 131 & 37.4 & 37.4 & 37.4 \\
\cline { 2 - 6 } & Male & 219 & 62.6 & 62.6 & 100.0 \\
\cline { 2 - 6 } & Total & 350 & 100.0 & 100.0 & \\
\hline
\end{tabular}

Source: Primary data of the study

Table- 1 is showing about the gender of respondents, which have been selected by the method of "simple-random sampling" technique. A total 131 female and 219 male respondents were found in the sample of total 350 number.

\section{CAREER OPPORTUNITY WITHIN ORGANIZATION}

Promotional policy in practice, the hotel gives enough recognition for well done work, on job employees have sufficient opportunities to use individuals personal talents and use the initiatives ,the management does a good job of keeping employees informed about matters affecting them, the skills have been enhanced for better career prospects, the hotel would seek ones' position with its growth, the hotel provides enough opportunity to learn for advancement, in opinion of individuals the outcome of training and development program were beneficial in the career development have been counted as the factors under Career Opportunity within organization.

Table 2 KMO and Bartlett's Test

\begin{tabular}{|l|l|l|}
\hline Kaiser-Meyer-Olkin Measure of Sampling Adequacy. & 607 \\
\hline \multirow{3}{*}{ Bartlett's Test of Sphericity } & Approx. Chi-Square & 1611.506 \\
\cline { 2 - 3 } & Df & 28 \\
\cline { 2 - 3 } & Sig. & .000 \\
\hline
\end{tabular}

Source: Compiled from primary data

The results of factor analysis are shown in table 2. The Kaiser-Meyer-Olkin Measure of Sampling Adequacy statistic indicates that the sample is adequate and the p-value of Bartlett's Test of Sphericity statistic (0.000) indicates that the correlation matrix of the variables considered in the study is not an identity matrix. This indicates that the factor analysis can be done on the data collected from the Employees.

Table 3 Rotation Sums of Squared Loadings

\begin{tabular}{|c|c|c|c|}
\hline \multirow{2}{*}{ Component } & \multicolumn{3}{|c|}{ Rotation Sums of Squared Loadings } \\
\cline { 2 - 4 } & Total & \% of Variance & Cumulative \% \\
\hline 1 & 3.185 & 39.809 & 39.809 \\
\hline 2 & 1.939 & 24.242 & 64.051 \\
\hline
\end{tabular}

Source: Compiled from primary data

The Communalities can be defined as the proportion of each variable's variance that can be explained by the principal components. It is also defined as the sum of squared factor 
loadings. The communalities of the variables including in the analysis is shown in the Table 3 . The results indicate that the communalities of all the variables are significant.

Table 4 Varimax Rotated Component Matrix for Career Opportunity within organization

\begin{tabular}{|c|c|c|c|c|}
\hline \multicolumn{3}{|l|}{ Rotated Component Matrix ${ }^{a}$} & \multirow[b]{2}{*}{ Mean } & \multirow[b]{2}{*}{$\begin{array}{l}\text { Std. } \\
\text { Dev }\end{array}$} \\
\hline & \multicolumn{2}{|c|}{ Factors } & & \\
\hline & \multicolumn{2}{|c|}{$\mathrm{CO} 1 \mathrm{CO} 2$} & & \\
\hline Promotional policy in practice & .501 & & 4.0314 & .51525 \\
\hline The Hotel gives enough recognition for well done work & & 684. & 3.9086 & .46994 \\
\hline $\begin{array}{l}\text { On my job, I have sufficient opportunities to use my personal talents and use } \\
\text { my initiatives. }\end{array}$ & .571 & & 4.1400 & .51937 \\
\hline $\begin{array}{l}\text { The Management does a good job of keeping me informed about matters } \\
\text { affecting me. }\end{array}$ & .724 & & 4.4629 & .58886 \\
\hline My skills have been enhanced for better career prospects. & .759 & & 3.7800 & .63800 \\
\hline The hotel would seek my position with its growth. & .801 & & 3.4171 & .56421 \\
\hline The hotel provides enough opportunity to learn for advancement. & & & 5.8086 & .59167 \\
\hline $\begin{array}{l}\text { In your opinion the outcome of training and development program were } \\
\text { beneficial in your career development }\end{array}$ & .734 & & 3.8114 & .52870 \\
\hline Reliability Cronbach's Alpha & .801 & 600 & & \\
\hline
\end{tabular}

Source: Compiled from primary data

The 8 items on career opportunity within the organization were grouped in to two factors $\mathrm{CO} 1$ and $\mathrm{CO} 2$. All the issues were found to be valid and reliable.

Table 5 Regression Analysis of Hypothesis

\begin{tabular}{|c|c|c|c|c|c|c|}
\hline \multicolumn{7}{|c|}{ For Garhwal Region } \\
\hline \multirow{2}{*}{\multicolumn{2}{|c|}{ Model }} & \multicolumn{2}{|c|}{$\begin{array}{c}\text { Unstandardized } \\
\text { Coefficients }\end{array}$} & \multirow{2}{*}{$\begin{array}{c}\text { Standardized } \\
\text { Coefficients } \\
\text { Beta }\end{array}$} & \multirow[t]{2}{*}{$\mathbf{T}$} & \multirow[t]{2}{*}{ Sig. } \\
\hline & & B & Std. Error & & & \\
\hline \multirow{3}{*}{1} & (Constant) & 15.555 & .781 & & 19.920 & .000 \\
\hline & $\mathrm{CO} 1$ & -.077 & .042 & -.186 & -1.852 & .066 \\
\hline & $\mathrm{CO} 2$ & .107 & .084 & .127 & 1.265 & .208 \\
\hline
\end{tabular}

\begin{tabular}{|c|c|c|c|c|c|c|}
\hline \multicolumn{7}{|c|}{ For Kumaun Region } \\
\hline \multirow{2}{*}{\multicolumn{2}{|c|}{ Model }} & \multicolumn{2}{|c|}{ Unstandardized Coefficients } & \multirow{2}{*}{$\begin{array}{c}\begin{array}{c}\text { Standardized } \\
\text { Coefficients }\end{array} \\
\text { Beta } \\
\end{array}$} & \multirow[t]{2}{*}{$\mathbf{T}$} & \multirow[t]{2}{*}{ Sig. } \\
\hline & & B & Std. Error & & & \\
\hline \multirow{3}{*}{1} & (Constant) & 15.351 & .949 & & 16.172 & .000 \\
\hline & $\mathrm{CO} 1$ & .001 & .043 & .003 & .034 & .973 \\
\hline & $\mathrm{CO} 2$ & -.093 & .096 & -.087 & -.970 & .333 \\
\hline
\end{tabular}

Source: Compiled from primary data

The factors related to "career opportunity", the regression models for Garhwal and Kumaun sample shown in table no. 5, are significant $F=1.717, p>.05$ and $F=.627, p>.05$ respectively. For the Garhwal region sample, it is evident that the factor CO1 (Promotional policy in practice, On my job, I have sufficient opportunities to use my personal talents and use my initiatives, The Management does a good job of keeping me informed about matters affecting me, My skills have been enhanced for better career prospects, The hotel would seek my position with its growth, In your opinion the outcome of training and development program were beneficial in your career development) has a significant negative relationship 
with employee attrition $(\mathrm{b}=-.077, \mathrm{p}>.05)$, i.e. if such issues are present then employee attrition will be less. Factor CO2 (The Hotel gives enough recognition for well done work, the hotel provides enough opportunity to learn for advancement.) has a significant positive relationship with employee attrition $(\mathrm{b}=.107, \mathrm{p}>.05)$, i.e. if such issues are present then employee attrition will be more. While in the Kumaun region sample, where CO1 factor had a positive relationship with employee attrition while CO2 has a significant negative relationship.

But it is evident that there is no significant effect of career opportunities on employee attrition for both the Garhwal and Kumon sample, as the overall regression model is not significant $\mathrm{F}=1.717$ and $\mathrm{F}=.627$ respectively with $\mathrm{p}>.05$. Hence the null hypothesis is rejected.

\section{CONCLUSION}

The research study the data collected from respondents as employees working in hotels of Garhwal and Kumaon regions have been analysed to come to the point as mentioned in the research objectives. The hospitality industry is flourishing day-to-day in Uttarakhand; and hence they need the manpower to work in hotels. The employers develop various HR strategies to retain their employees in hotels for longer. Although, the hospitality industry is facing a lot of challenges; it has a long lean period in winters, but the employers try to retain the minimum number of potential and dedicated employees in their hotel. Since the employees are working in hotels generally from the local area around the hotels. They find the similar opportunities in the hotels which are nearby their home and village, as they will get in the metropolitan cities. They also understand that there are many expenses, while they are leaving their present job and moving towards the other cities. Understanding the issues related to career opportunities, the employers pay fairly to the employees so that they should retain in the job. Employers do take care of the promotional policies for their present employees. On the job, employee also feel that their talents are being recognised by the management. The skills of employees are enhanced through various training programs for better career prospects.

\section{REFERENCES}

[1] Agrusa, J., \& Lema, J. D. (2007). An Examination of Mississippi Gulf Coast Casino Management Styles with Implications for Employee Turnover. UNLV Gaming Research \& Review Journal, 11(1), 13-26.

[2] Anthony, A \& Irene, S. (2014). 'Leadership challenges in Ghana's hotel industry: Effective motivation for the human resource sector', Journal of Humanities and Social Science, Vol. 2 (1), pp. 1-11, January 2014.

[3] Bettye L. Holston-Okae, (2018). The Effect of Employee Turnover in the Hospitality Industry: Quantitative Correlational Study, International Journal of Learning and Development; ISSN 2164-4063 2018, Vol. 8, No. 1

[4] Bharwani, S. \& Butt, N., 2012. 'Challenges for the global hospitality industry: an HR perspective'. Worldwide Hospitality and Tourism Themes, 4(2), pp. 150-162.

[5] Bursch, J., 1999. 'Well-structured employee reward/ recognition programs yield positive results'. HR Focus, 76(11), pp. 1-14.

[6] Chikwe, A.C. (2009). The impact of employee turnover: The case of leisure, tourism and hospitality industry. Consortium Journal of Hospitality \& Tourism, 14(1), 43-56.

[7] Davidson, M.C.G., McPhail, R., \& Barry, S. (2011). Hospitality HRM: past, present and the future. International Journal of Contemporary Hospitality Management, 23(4), 498- 516. 
[8] Deery, M.A. and Shaw, R. N. (1997), 'An exploratory analysis of turnover culture in the hotel industry in Australia', International Journal of Hospitality Management, Vol. 16 No. 3, pp. 375-392.

[9] Folakemi, O., Anthonia, A., Gbenga, O., Friday, I., Odunayo, S., Adekunle, S., (2020). Talent Retention Strategies and Employees' Behavioural Outcomes: Empirical Evidence from Hospitality Industry, Verslas: Teorija ir praktika / Business: Theory and Practice ISSN 1648$0627 /$ eISSN 1822-4202, 2020 Volume 21 Issue 1: 192-199, https://doi.org/10.3846/btp.2020.11061

[10] Folakemi, O., Anthonia, A., Olumuyiwa, O., Omotayo. O., (2018). Perception of Frontline Employees towards Career Growth Opportunities: Implications on Turnover Intention, Verslas: Teorija Ir Praktika / Business: Theory And Practice; ISSN 1648-0627 / eISSN 18224202, http://btp.press.vgtu.It 2018 19: 278-287 https://doi.org/10.3846/btp.2018.28

[11] Huanga, Y., Lee, J., McFadden, A., Lauren A., Murphyad, L. Robertson, M., Cheung, J., Zohar, D., (2016). Beyond Safety Outcomes: An Investigation of The Impact of Safety Climate on Job Satisfaction, Employee Engagement and Turnover Using Social Exchange Theory as The Theoretical Framework; Applied Ergonomics, Volume 55, July 2016, Pages $248-257$

[12] Honore, J. (2009). Employee Motivation. Consortium Journal of Hospitality \& Tourism, 14(1), 63-75.

[13] Iqbal, S., Guohao, L. \& Akhtar, S. (2017). Effects of job organizational culture, benefits, salary on job satisfaction ultimately affecting employee retention. Review of Public Administration and Management, 5(3).

[14] Kara, D., Uysal, M. \& Magnini, V. P., (2012). 'Gender differences on job satisfaction of the five-star hotel employees'. International Journal of Contemporary Hospitality Management, 24(7), pp. 1047-1065.

[15] Kemelgor, B. H. \& Meek, W. R., (2008). 'Employee Retention In Growth-Oriented Enterprenurial Firms: An Exploratory Study'. Journal of Small Business Strategy, 19(1), pp. $74-86$.

[16] Lashley, C. And Chaplain, A. (1999),'Labor turnover: hidden problem - hidden costs', The Hospitality Review, Vol. 1 No. 1, pp. 49-54

[17] Levine, R. (2005). A Hassle-Free Approach to Worker Retention. Lodging Hospitality, 61(6), 24.

[18] Martin, J. (2010). How to keep your top talent. Harvard Business Review, 88(5), 54-61. Armstrong, M., 2012. 'Armstrong's Handbook of reward management and practice improving performance through reward'. 4th ed. London: Kogan Page.

[19] Moncarz, E., Zhao, J., \& Kay, C. (2009). An Exploratory Study of U.S. Lodging Properties' Organizational Practices on Employee Turnover and Retention. International Journal of $\begin{array}{lllll}\text { Contemporary Hospitality } & \text { Management, } & \text { 21(4), }\end{array}$ doi:10.1108/09596110910955695

[20] Padron, T. (2004 Aug.). Retention of Employees in the Wisconsin Restaurant Industry. Unpublished Master's Thesis, University of Wisconsin-Stout, Menomonie.

[21] Panoch, A. (2001 May). The Relationship between Diversity and Employee Retention. Unpublished Master's Thesis, University of Wisconsin-Stout, Menomonie.

[22] Rasheeda, M., Okumusb, F., Wengc, Q., Hameedd, Z., Nawaz, M. (2020). Career Adaptability and Employee Turnover Intentions: The Role of Perceived Career Opportunities and Orientation to Happiness in the Hospitality Industry; Journal of Hospitality and Tourism Management. DOI: 10.1016/j.jhtm.2020.05.006 
The Impact of Career Opportunities on Employee Retention in Hospitality Industry: A Comparative Study of Garhwal and Kumaun Region of Uttarakhand

[23] Richardson, S. A. (2008). Undergraduate tourism and hospitality students' attitudes towards a career in the industry: A preliminary investigation. Journal of Teaching in Travel and Tourism, 8(1), 23-46.

[24] Robinson, R. N. S., \& Beesley, L. G. (2010). Linkages between creativity and intention to quit: An occupational study of chefs. Tourism Management, 31(6), 765-776. http://dx.doi.org/10.1016/j.tourman.2009.08.003

[25] Salie, S., Schlechter, A., (2012). A formative evaluation of a staff reward and recognition programme, SA Journal of Human Resource Management, DOI: 10.4102/sajhrm.v10i3.422

[26] Syahreza, D., Lumbanraja, P., Dalimunthe, R., \& Absah, Y. (2017). Compensation, employee performance, and mediating role of retention: a study of differential semantic scales. European Research Studies Journal, 20, 151-159.

[27] Taylor, S. (2008). People Resourcing (4th ed.), Staff Turnover and Retention (pp. 431-452). London: Chartered Institute of Personnel and Development.

[28] Vetráková, M., Šimo`cková, I and Pompurová, K., (2019). Age and Educational Diversification of Hotel, Employees and Its Impact on Turnover, Sustainability 2019, 11, 5434; doi:10.3390/su11195434 www.mdpi.com/journal/sustainability

[29] Yifei, L., (2018). Career Growth and Turnover Intention: The Mediator Role of Career Commitment and Organizational Identification. Dissertation submitted for Master in Human Resource Management 